\title{
The Performance of Sharia Equity Fund Investment Manager
}

\author{
Anni Maftukhah \\ Muhammadiyah University Purworejo \\ E-mail: annimaftukhah@gmail.com
}

\begin{abstract}
,
Sharia mutual funds are fund raising activities from investors to be managed by investment managers with sharia-based management, namely by not investing funds in companies whose types and scope of business are not in accordance with Islamic sharia. This study was conducted to determine the effect of turnover ratio, expenses ratio, fund size, managerial tenure, and fund selection skills on the performance of sharia mutual fund investment managers in Indonesia. The data used in this study are monthly Net Asset Value, BI rate, IHSG, annual turnover data, annual expenses ratio data, and prospectus of 9 sharia stock mutual funds from December 2014 to December 2018. Samples were taken based on the purposive sampling method during this research. The measurement of the performance of sharia equity fund investment managers uses the Sharpe Ratio method. The method used is multiple linear regression analysis and classic assumption tests using descriptive statistical tests, multicollinearity tests, and heteroscedasticity tests using EVIEWS 10 statistical software. The results of this study indicate that turnover ratio, fund size, fund selection skills significantly influence performance Islamic mutual fund investment manager. While expenses and managerial tenure ratios do not significantly influence the performance of investment managers in Islamic mutual funds.
\end{abstract}

Keywords: Investment Manager Performance, Mutual Fund Characteristics

\section{INTRODUCTION}

One country's economic progress can be reflected in capital market activities in that country. Investment is a sacrifice made by someone at this time to get rewards according to their expectations in the future (Iman, 2008: 4). In relation to investment in the capital market, investment growth in Indonesia in the 2013-2019 period tends to fluctuate. In a situation of fluctuating investment growth, one investment instrument in the capital market, namely mutual funds, has experienced the opposite. The decline in total investment that occurred signaled economic instability. Investors invest their capital to get as many returns as possible, so they tend to avoid economic instability. In a risky situation, as an investor, It is important to have a capable ability to minimize losses. This phenomenon causes the public to prefer investment in a safe manner, thus requiring experts as managers of their funds.

Mutual funds basically collect capital in the form of money from investors with varying amounts to then be managed collectively by investment managers (Iman, 2008: 27). The growth of sharia and conventional mutual funds is equally volatile, but sharia mutual funds grow with a higher fluctuation niche. Total Net Asset Value (NAV) of sharia mutual funds and conventional mutual funds are adrift. The limitation set by the National Sharia Board is the business sector (core business) which must be in accordance with sharia principles and financial ratios in the form of debt to equity ratio (DER) which must not exceed $82 \%$. This limit causes the choice of sharia effects to be quite limited, not even including some blue chip category effects. As a result, Investment returns only depend on the expertise of the investment manager or manager. Equity funds have great potential as a long-term investment option. This is 
supported by investment trends that continue to grow and also the value of the Indonesia Sharia Stock Index (ISSI) which increases every year.

Mutual fund investment managers are influenced by mutual fund characteristics, such as: (1) turnover ratio (Anderson, et al., 1996: 203, Cuthbertson, Nitzsche, and O'Sullivan, 2010: 95); (2) expenses ratio, (Sharpe, 1966: 119; Malkiel, 1995: 549; Ciccotello and Grant, 1996: 365; Carhart, 1997: 57); (3) fund size (Grinblatt and Titman, 1989: 419, Chen, et al., 1992: 659; Ciccotello and Grant, 1996: 365, Indro, et al., 1999: 74); (4) managerial tenure (Khorana, Nelling, and Edward, 1998: 61; Afza and Rauf, 2009: 199); (5) fund selection skills (Fama, 1972: 551; Kon and Jen, 1979: 261; Chen, et al., 1992: 659). In addition, the results of Mulyawan's research (2016) found that turnover ratios, expenses ratios, fund sizes, managerial tenure and fund selection skills influence the performance of Islamic mutual funds.

Mutual funds that have high turnover ratios indicate that Investment Managers carry out high frequency buying and selling portfolio activities, which means the mutual fund's trading activity is very high. The higher the portfolio turnover rate, the greater the possible return. The condition of mutual funds with high turnover results in better performance whereas mutual funds with low turnover produce worse performance (Grinblatt and Titman, 1994). Different results were found by Sukmaningrum and Mahfudz (2016) that the turnover ratio did not significantly influence mutual fund performance.

Expenses ratiois a comparison between the operational burden of managing mutual funds with the average NAV. This ratio is a comparison of how much the cost must be paid by investors each year (Iman. 2008: 117). Choosing a mutual fund with a low expenses ratio ( $1 \%$ or less) will give better results. Fees that are too large will eventually erode potential profits (Iman, 2008: 122). Meanwhile, according to Satrio and Mahfudz (2016), expenses ratio has a significant positive effect on mutual fund performance.

According to Chen, et al., (1992) Fund size can be described by the amount of assets managed by a mutual fund company. Wealth in general shows the economies of scale of a company. The larger the scale of the company's economy, the greater the size of the company. According to research conducted by Satrio and Mahfudz (2016) that mutual funds with a larger size can show better performance.

Managerial Tenure or age of management position according to Chen (2018) is the length of time managers manage mutual funds. Note that long-term performance is preferably in the range of 5 to 10 years, because it is considered a key indicator of the ability of Investment Fund Managers. Mutual fund investors are considered best served by Investment Managers who have proven themselves over a long period of time. Fund Selection Skill defined by Fama (1972) as an ability investment managers to choose assets to form a portfolio that is predicted to provide expected returns in the future.

It is important for potential investors or existing investors to know the performance of selected mutual fund investment managers, so as to minimize the risk of loss, and earn returnwhich is desired. This study examines the performance of Investment Managers in the period 2015-2018, because in the period of 2015 the rate 
of development of NAV has decreased and then the following year has experienced a very large increase. The performance of Islamic mutual fund is measured using the methodSharpe Ratio.

Previous research showing intermediate influence turnover ratio, expenses ratio, fund size, managerial tenure, and fund selection skills on mutual fund performance provide quite diverse research results. Based on the explanation, the researcher is interested in re-examining the effect of turnover ratio, expenses ratio, fund size, managerial tenure, and fund selection skills on the performance of Islamic mutual fund.

\section{LITERATURE REVIEW}

Based on the National Sharia Board Fatwa No. 20 / DSN-MUI / IX / 2000 "Sharia mutual funds are mutual funds that operate according to Islamic sharia principles and principles, both in the form of inter-investor agreements as owners of assets (sahib al-mal / rabb al-mal) with investment managers as sahib al representatives -mal, and between investment managers as representatives of sahib al-mal and investment users ". Sharia Mutual Fund Shares (RDS) are sharia mutual funds that invest at least $80 \%$ of the portfolio they manage into equity securities (shares).

To get a favorable return value, users of Islamic mutual funds must ensure that the selected investment manager has the ability to provide returns as expected. The selected investment manager must be of good quality and trustworthiness. Investment manager expertise can be seen from the performance of the last few years (Iman, 2008: 101). Consistent past performance in the long run is a clue to the potential of mutual funds in the future (Pratomo and Nugraha, 2009: 152).

The investment manager's performance can be measured by the Sharpe index. The Sharpe Index bases its calculations on the concept of a capital market line (capital market line) or better known as the Reward to Variability Ratio (RVAR) as a benchmark by dividing portfolio risk premium by its standard deviation. The purpose of the Sharpe Index is to measure the extent of optimal portfolio diversification that produces profits with certain risks. The higher the Sharpe measurement value, the better the mutual fund performance.

According to Chen, et al, (1992), the performance of a security including mutual funds is influenced by external factors such as the state of a country's economy and factors attached to mutual funds (related to mutual fund managers, namely investment managers). From the aspect of factors inherent in the mutual fund itself, several studies have shown that mutual fund performance is influenced by mutual fund characteristics such as turnover ratio, expenses ratio, fund size, managerial tenure, and fund selection skills. The high turnover ratio shows that Investment Managers really anticipate market changes such as various existing issues, and the condition of mutual funds with high turnover results in better performance and mutual funds with low turnover results in worse performance (Grinblatt and Titman, 1994). 
Iman (2008: 117) explains that the expenses ratio is a comparison of how much the cost must be paid by investors every year. The higher the total costs required in managing a mutual fund portfolio, the lower investment returns from investors are reflected in a decrease in mutual fund returns (Sukmaningrum, 2016). Iman (2008: 122) argues that a fee that is too large will eventually erode the profit potential. Paying a large fee does not mean getting better quality. According to research conducted by.

Satrio and Mahfudz (2016) that mutual funds with a larger fund size can show better performance. Mutual funds with large asset levels can hold high market capitalization. Khorana, Nelling, and Edward (1998) explain that good mutual fund performance has investment managers who have longer experience. According to Iman (2008: 109) new investment managers, who are in the last 2-3 years, do not yet have an accurate track record. It is possible that the success of the mutual fund that it manages is the result of the hard work of its predecessor investment manager.

According to Sabila et al. (2019) argue that abilityfund selection skillthis is closely related to the fundamental analysis capability of securities. The better the fund selection skills possessed by investment managers, the better the performance of Islamic mutual funds in providing expected returns.

\section{METHODS}

This research is a research in the form of causal research. The purpose of this study is to measure the relationship between two or more variables and show the direction of the relationship between the independent variable and the dependent variable (Kuncoro, 2013: 15). The time dimension of this research involves a lot of time in a certain order and a lot of samples (pooled data), namely the investment manager of Islamic mutual funds listed on the Indonesia Stock Exchange for the period 20152018. The sample of this research is 9 investment managers of Islamic mutual fund shares. The dependent variable in this study is the performance of investment managers. The independent variables in this study are turover ratio, expenses ratio, fund size, managerial tenure, and fund selection skills. The operational definitions of the variables are as follows:

1. In this study the performance of mutual fund investment managers is measured using the Sharpe Index. With the Sharpe method, it is intended that if a mutual fund has a return other than a positive return, the return of the mutual fund should also be above the risk-free return instrument. The greater the value of the Sharpe ratio, the better the performance of the mutual fund investment manager. Sharpe index can be formulated as follows:

Where,

$$
\mathrm{RVAR}=\left[\mathrm{R}_{\mathrm{p}}-\mathrm{Rf}\right] / \mathrm{SDp}
$$

$$
\begin{array}{ll}
\mathrm{RVAR} & =\text { Sharpe Index } \\
\mathrm{R}_{\mathrm{p}} & =\text { Average Return of a Portfolio in a Period } \\
\mathrm{Rf} & =\text { Average Risk-free rate (Indonesian Interest Rates) } \\
\mathrm{SDp} & =\text { Standard Deviation of a Portfolio Return for a Period }
\end{array}
$$


Explanation of the details of the Sharpe model measurement results obtained from several inseparable stages, namely:

a. Looking for the return of each mutual fund per month, mutual fund returns can be calculated using the formula:

Where,

$$
R p=\frac{N A B_{t}-N A B_{t-1}}{N A B_{t-1}}
$$

$\mathrm{R}_{\mathrm{p}} \quad=$ Portfolio return

$\mathrm{NABt} \quad=$ Net asset value in period $\mathrm{t}$

NAB-1 = Value of net assets in the previous period

b. $R_{m}$ as a market return is calculated by the following formula:

$$
\mathrm{R}_{\mathrm{m}}=\frac{\mathrm{IHSG}_{\mathrm{t}}-\mathrm{IHSG}_{\mathrm{t}-1}}{\mathrm{IHSG}_{\mathrm{t}-1}}
$$

Where,

$\mathrm{R}_{\mathrm{m}} \quad=$ Return market

IHSG = Period composite stock price index $\mathrm{t}$

IHSG t 1 = Composite stock price index of the previous period

c. The average risk free interest rate (BI rate) is formulated as follows:

Where,

$$
\mathrm{R}_{\mathrm{f}}=\frac{\sum \text { BI Rate }}{\mathrm{n}}
$$

$$
\begin{array}{ll}
\mathrm{R}_{\mathrm{f}} & =\text { Risk free (risk free interest rate) } \\
\Sigma \text { BI Rate } & =\text { Amount of interest } \\
\mathrm{n} & =\text { Number of observation periods }
\end{array}
$$

d. Standard deviation, the standard used to calculate the total risk (systematic and non-systematic risk) of all investment instruments, the calculation of the standard deviation can be done using the STDEV formula in Microsoft Excel software.

2. Turnover ratio can be calculated by dividing the total sales or the smallest total asset purchases divided by the average assets managed over a period or one year.

$$
\mathrm{TR}=\text { Total Sales } \div \text { Average assets managed in one year }
$$

3. Expenses ratio is a comparison between the operational expenses of managing a mutual fund and the average Net Asset Value (NAV).

$$
\mathrm{ER}=\text { Operating Expenses } \div \mathrm{NAV}
$$

4. According to Chen, et al., (1992) fund size can be described by the amount of assets managed by a mutual fund company. . After the total net assets are obtained, it is then converted to Ln. Fund Size can be formulated as follows:

$$
\mathrm{FS}=\mathrm{Ln}(\mathrm{NABt})
$$

5. Managerial tenure is measured using the length of time the Investment Manager manages certain mutual funds (expressed in years). 
6. Fund Selection Skills can be determined by using the Treynor-Mazuy model. Treynor-Mazuy (1966) uses quadratic regression techniques to identify nonlinear changes in systematic risk. Values and significance in the Treynor-Mazuy model show fund selection skills, while squared coefficients indicate market timing abilities. This model explains the ability of investment managers to conduct fund selection skills and market timing abilities, by performing a regression between excess portfolio return as a dependent variable with excess market return and excess market return squared as the independent variable. The Treynor Model-Mazuy, a represents the ability of investment managers to conduct fund selection skills, and is said to have this ability when $\alpha$ is significantly positive. This indicates that investment managers produce greater excess return on mutual fund portfolios compared to excess market return. Fund selection skills are dummy variables, where o represents a negative insignificant $\alpha$ value indicating that investment managers are unable to conduct fund selection. Figure 1 represents the ability of investment managers to conduct fund selection, where the value of $\alpha$ is positive and significant. The Treynor and Mazuy models used in this study are: Figure 1 represents the ability of investment managers to conduct fund selection, where the value of $\alpha$ is positive and significant. The Treynor and Mazuy models used in this study are: Figure 1 represents the ability of investment managers to conduct fund selection, where the value of $\alpha$ is positive and significant. The Treynor and Mazuy models used in this study are:

Where:

$$
\mathrm{Rp}-\mathrm{Rf}=\alpha p+\beta p(\mathrm{Rm}-\mathrm{Rf})+\gamma(\mathrm{Rm}-\mathrm{Rf}) 2+\varepsilon p
$$

$$
\begin{array}{ll}
\mathrm{Rp} & =\text { Portfolio return } \\
\mathrm{Rf} & =\text { Return of assets risk free } \\
\mathrm{Rm} & =\text { Return market } \\
\alpha \mathrm{p} & =\text { Parameter used as an indication fund selection skill from the } \\
& \text { investment manager } \\
\beta \mathrm{p} \quad & \text { Excess regression coefficient market return or slope on market } \\
& \quad \text { time down } \\
\mathrm{\gamma} \quad & \text { Parameters used as an indication of ability market timing ability } \\
& \quad \text { from investment manager }
\end{array}
$$

The calculation component in finding Fund selection skill values using the Treynor - Mazuy model includes:

a. Return de-calculated mutual fund portfolio with the formula:

Where,

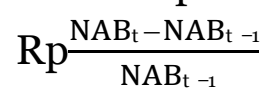

$\mathrm{Rp} \quad=$ Portfolio return

NABt $=$ Net asset value in period $t$

NAB $-1=$ Value of net assets in the previous period 
b. Return on assets Risk-free calculated by the formula:

Where,

$$
\mathrm{Rf}=\frac{\mathrm{R}_{1 \mathrm{t}}+\mathrm{R}_{2 \mathrm{t}}+\mathrm{R}_{\mathrm{nt}}}{\mathrm{n}}
$$

$$
\begin{array}{ll}
\mathrm{R}_{\mathrm{f}} & =\text { Return is risk free } \\
\mathrm{Rnt} & = \\
& \text { Interest rate of Bank Indonesia Certificate (SBI) for } \\
& \text { period } \mathrm{t} \\
\mathrm{n} & =
\end{array}
$$

c. Return The market is calculated according to the formula:

$$
\mathrm{Rm}=\frac{\mathrm{IHSG}_{\mathrm{t}}-\mathrm{IHSG}_{\mathrm{t}-1}}{\mathrm{IHSG}_{\mathrm{t}-1}}
$$

Where :

$$
\begin{array}{ll}
\mathrm{Rm} & =\text { Market return } \\
\text { IHSG } & =\text { IHSG period } \mathrm{t} \\
\text { IHSGt1 } & =\text { IHSG of the previous period }
\end{array}
$$

Making conclusions regarding the presence or absence of fund selection skills in investment managers using the Treynor Mazuy method based on the following criteria (Chu \& McKenzie, 2008):

a. If the value of $\alpha$ (alpha) $>0$, t-stat $>t$-table and $p$-value $<0.05$, this indicates a fund selection skill.

b. If the value of $\alpha$ (alpha) $<0$, t-stat $>$ t-table and $p$-value $<0.05$, this indicates that there is no fund selection skill.

Data collection was carried out in this study using the archive method (archival). Archive method is a method of data collection which is done by collecting records or existing databases (Jogiyanto, 2016: 100). The documents used in the study are annual financial data obtained from prospectuses and financial reports.

Before entering the linear regression, the function must pass the descriptive statistical test and the classical assumption test. There are 2 things that must be tested in classical assumptions: multicollinearity, heteroscedasticity. Hypothesis testing is needed to determine the significance of the results of calculations with Regression using Eviews 10. The testing method used in this study is the t test and analysis of the coefficient of determination (r square).

\section{DISCUSSION}

The amount of data on each valid variable (valid for processing) is 36 . The investment manager performance variable (RVAR) has an average value of 0.207 with a large deviation of 0.678 . Variable Turnover Ratio (TR) has an average value of 1.544 with a large deviation of 1.6569. Expenses Ratio (ER) has an average value of 0.039 with a large deviation of 0.0125. Variable Fund Size (FS) has an average value of 24,729 with a large deviation of 2.2370. The Managerial Tenure (MT) variable has an average value of 7.388 with a large deviation of 3.3147. Variable Fund Selection Skill (FSS) has an average value of 0.166 with a large deviation of 0.3779. Standard deviation is a measure that describes the level of data spread from the average value. The smaller the standard deviation is close to the mean, the smaller the distribution of data, so that 
the data used is accurate (Pambuko, 2018: 23). The multicollinearity test results showed that the VIF value on turnover ratio, expense ratio, fund size, managerial tenure, and fund selection skills was less than 10, so it can be concluded that this regression model did not contain symptoms of multicollinearity. Heteroscedasticity test results using the Glejser test Probability value on Expenses Ratio, Fund Size, Managerial Tenure, and Fund Selection Skill variables are greater than 0.05 so it can be concluded that there is no heteroscedasticity problem. While the Turnover Ratio variable has a probability value of $0.0403<0.05$ which indicates that there is a heteroscedasticity problem. Therefore, it can be concluded that the Glejser test indicates a heteroscedasticity problem in the model.

Therefore, correction or treatment of heteroscedasticity is needed. Correction of the heteroscedasticity problem in this study was carried out using White's Heteroscedasticity-Consistent Variance and Standard Error to correct the parameter values obtained by the OLS method. The results of heteroscedasticity correction with the White procedure are compared with the results of OLS regression without correction, said to be successful if the correction results do not change the conclusion of the hypothesis testing results where the significance value and the coefficient sign remain the same. This indicates that heteroscedasticity is not a serious problem in the regression model so that it can be directly used as the final result of hypothesis testing (Ghozali and Ratmono, 2017: 102).

\section{H1: Turnover Ratio has a positive effect on Investment Manager Performance}

Regression test results showcoefficientvariable turnover ratio $=-0.152$ with a probability value $=0.0124(<0.05)$ which means significant. This means that the turnover ratio has a negative effect on the performance of investment managers. Means $\mathrm{H} 1$ is not acceptable. The testing of the first hypothesis does not prove that the turnover ratio has a positive effect on the performance of investment managers in Islamic mutual funds. Turnover ratios indicate the manager's investment style, whether active transacting or passive. Nguyen et al. (2018) states that an active policy seen from a high turnover ratio actually makes investment managers more difficult, even in liquidity. Whereas the low, or passive, turnover ratio has been proven to improve investment manager performance. Investment managers who focus on the quality of the chosen portfolio, will produce a definite return, compared to investment managers who focus on portfolio quantities. Low return on ratio according to Iman (2008: 117) identifies that investment managers choose a buy and hold strategy of stock, which is a characteristic typical long-term investment.

According to Seal (2020) Equity funds with small capitalization growth tend to be more aggressive, which generally will experience a change in portfolio composition. Whereas equity funds with large capitalization tend to be more passive with low turnover rates. Stocks with large market capitalization were chosen because they have good fundamentals so they do not waver when negative sentiments occur in the capital market. Chen et al. (2016) also mentions that added mutual funds, do not necessarily produce better performance, compared to mutual funds issued from their portofolio. 
The results of this study are in line with research conducted by Charhart (1997), Gallagher (2003), Satrio and Mahfudz (2016) and Sukmaningrum and Mahfudz (2016) which show a negative relationship between turnover and investment manager performance. The results of this study differ from the results of research conducted by Mulyawan (2016) which shows a positive and significant relationship to the performance of mutual fund investment managers.

\section{H2: Expenses ratio has a negative effect on the performance of Investment}

\section{Managers}

Based on the results of the regression test that has been done, the value of the expense ratio variable has a probability value $>a(0.9270>0.05)$ indicating that the expense ratio has no effect on the investment manager's performance, so $\mathrm{H} 2$ is rejected. Tests conducted on the second hypothesis, unable to prove that the expense ratio has a significant negative effect on the performance of investment managers in Islamic equity funds. The results of this study indicate that the expenses ratio does not affect the performance of investment managers. This shows that the size of the operational costs used in Islamic stock mutual fund companies, does not affect the performance of investment managers of Islamic stock mutual funds.

Investment managers in carrying out their strategies require costs, such as marketing costs, management costs, administrative costs, operating costs. So, the costs incurred by equity fund companies follow what strategies are implemented by investment managers. Hayes (2020) explains that trading, buying and selling portfolio or turnover activities are not included in the calculation of expenses ratios. This is in line with the opinion of Folger (2020) that the expenses ratio is an operational cost that represents investors' funds to own mutual funds, not buy or redeem mutual funds (turnover ratio). Any initial sales costs, or deferred, transaction costs in this case are brokerage fees not included in the expense ratio. This explanation provides a reason why expenses ratio does not affect the performance of equity funds, because the size of the costs incurred only follows the strategy adopted by the investment manager. Thus, the performance of equity funds is not influenced by the amount of costs incurred, but from what strategies are used by investment managers.

Mutual funds are basically investment instruments that offer security to investors. On average, investors choose mutual funds because of guaranteed returns and investment expertise. Therefore, mutual fund investors in Indonesia do not focus on operational costs incurred, but rather on the level of investment security and the resulting performance. The results of this study differ from studies conducted by Satrio and Mahfudz (2016) which state that the expense ratio has a significant positive effect on the performance of mutual fund investment managers. However, the results of this study are in line with research conducted by Harjono, et al (2017) which states that the expense ratio has no effect on the performance of investment fund managers.

H3: Fund Size has a positive effect on the performance of Investment Managers

Based on the results of the regression tests that have been carried out, the fund size variable value has a probability value $<\alpha(0.0096<0.05)$ indicating that the fund size significantly influences the investment manager's performance. The coefficients 
are negative (-0,083), it means, every fund size increases, the investment manager's performance will decrease. $\mathrm{H}_{3}$ is rejected, fund size has a significant negative effect on the performance of investment managers.

Tests conducted on the third hypothesis, unable to prove that fund size has a significantly positive effect on the performance of investment managers in Islamic equity funds. The results of this study indicate that the greater the number of assets managed by an investment manager, the lower the investment manager's performance in managing sharia equity funds. The smaller asset size will make it easier for investment managers to manage their portfolio and liquidity well (Prabowo, 2018). Meanwhile, the large amount of funds held by investment managers will have complexity in managing these funds and allocating them to other assets, this causes disruption of liquidity.

Large size investment managers will experience liquidity difficulties when there is a massive withdrawal by investors, thereby reducing the return of funds and then reducing its performance. This study contradicts research conducted by Mulyawan (2016) which states that fund size has a significantly positive effect on the performance of investment managers. This research is supported by research conducted by Syahid (2015) which states that fund size has a significant negative effect on the performance of investment managers.

\section{H4: Managerial Tenure has a positive effect on Investment Manager Performance}

Based on the results of the regression test that has been done, the managerial tenure variable value has a probability value $>a$ (0.8877> 0.05$)$ indicating that managerial tenure has no effect on the investment manager's performance, so $\mathrm{H}_{4}$ is rejected. Tests carried out on the fourth hypothesis, unable to prove that managerial tenure has a significantly positive effect on the performance of investment managers in Islamic equity funds. The results of this study indicate that the length of time an investment manager manages a mutual fund does not affect the level of performance produced by the investment manager. Each investment manager has their own policies and strategies for managing mutual funds. Some management tends to be aggressive even though they have experience, some tend to be conservative and careful in making decisions. Every investment manager who manages equity funds has its own considerations in preparing and managing mutual fund portfolios (Prabowo, 2018).

This is in line with research conducted by Porter and Thrif (2014) which states that investment manager performance is influenced by the risk-taking style of investments taken. While managers with long tenure do not guarantee their performance is superior to managers with new tenure. This study contradicts research conducted by Sukmaningrum and Mahfudz (2016) which states that managerial tenure has a positive effect.

\section{H5: Fund selection skills have a positive effect on the performance of Investment Managers.}

Regression test results indicate that the variable fund selection skill has a probability value $<\alpha(0.0096<0.05)$, which means significant. This means that fund selection skills significantly influence Investment Manager Performance. The 
coefficients indicate positive (1,190), that is, every fund selection skill increases, the investment manager's performance will also increase. $\mathrm{H}_{5}$ is accepted, fund selection skills have a significant positive effect on the performance of investment managers. Tests conducted on the fifth hypothesis, able to prove that fund selection skills significantly positive effect on the performance of investment managers in Islamic equity funds. Fund selection skills describe the ability of investment managers to select assets to form a portfolio that is predicted to provide expected returns in the future.

Investment managers more often rely on the ability to choose securities to get an abnormal return (superior). The findings of this study support the conclusions of Fama's research (1972) which developed a method to distinguish returns as a result of the ability of fund selection at a certain risk level by predicting market price movements and arguing the relationship between portfolio returns and fund selection. The results of Kon and Jen's research (1979: 261) also showed that statistically the overall fund selection skill had a significant positive effect on the performance of investment managers. This study contradicts the results of research conducted by Syahid (2015) which states that fund selection skills have a significant negative effect on the performance of mutual fund investment managers.

\section{CONCLUSION}

Based on the results of data analysis, it can be concluded that the following: turnover ratio has a negative effect on the performance of Islamic mutual fund investment managers. Expenses ratio does not affect the performance of sharia equity fund investment managers. Fund size has a negative effect on the performance of Islamic equity fund investment managers. Managerial tenure does not affect the performance of sharia equity fund investment managers. Fund selection skills have a positive effect on the performance of Islamic equity fund investment managers.

Based on the conclusions, suggestions that can be given for further research related to the analysis of the performance of mutual fund investment managers in Indonesia, namely by adding independent variables that are thought to affect the performance of mutual fund investment managers, such as fund cash flow and market timing abilities.

\section{REFERENCES}

Anderson, S.B., D. Coleman, Gropper and Sunquist H. 1996. A Comparison of The Performanceof Open and Closed End Investment Companies. Journal of Economicand Finance, 203-211.

Badan Koordinasi Penanaman Modal (BKPM). Statistik Realisasi Penanaman Modal Asing (PMA) Periode Oktober-Desember 2013-2019. www.bkpm.go.id. diakses 2020.

Badan Koordinasi Penanaman Modal (BKPM). Statistik Realisasi Penanaman Modal Dalam Negeri (PMDI) Periode Oktober-Desember 2013-2019. www.bkpm.go.id. diakses 2020. 
Carhart, M. M. 1997. On Persistance in Mutual Fund Performance. Journal of Finance, 52(1), 57-82.

Chen, C., F. Cheng, S. Rahman and A. 1992. Chan. Cross Sectional Analysis of Mutual Fund's Market Timing and Security Selection Skill. Journal of Business Finance and Accounting, 19, 659-674.

Chen, H.C., Lai, C.W., and Wu, S.C. 2016. Mutual Fund Selection and Performance Persistence in 401(k) Plans. North American Journal of Economics and Finance, 35, pp 78-100.

Chen, James. 2018. Management Tenure. www.investopedia.com. Diakses 3 Juni 2020.

Chu, Patrick Kuok-kun dan McKenzie, Michael. 2008. A Study on Stock-Selection and Market-Timing Performance : Evidence from Hong Kong Mandatory Provident Funds (MPF). Review of Pacific Basin Financial Markets and Policies (RPBFMP), 11(4), 617-649.

Ciccotello, Conrad S., and Grant C. Terry. 1996. Equity Fund Size and Growth: Implications forPerformance and Selection. Financial Services Review, 5(1), 365-380.

Cuthbertson, Keith, Dirk Nitzsche and Niall O’Sullivan. 2010. Mutual Fund Performance: Measurement And Evidence. Journal of Financial Markets, Instruments and Institutions, 19(2), 95-187.

Fama, E. 1972. Component of Investment Performance. Journal of Finance, 27(3), $551-567$.

Folger, Jean. 2020. Pay Attention to Your Fund's Expense Ratio. www.investopedia.com. Diakses 14 Juli 2020.

Ghozali, Imam. 2011. Aplikasi Analisis Multivariate dengan Program IBM SPSS 21. Cetakan Ke 7. Semarang: Badan Penerbit Universitas Diponegoro.

Ghozali, Imam dan Ratmono, Dwi. 2017. Analisis Multivariat dan Ekonometrika Teori, Kon sep dan Aplikasi dengan Eviews 10 Edisi 2. Semarang: Badan Penerbit Universitas Diponegoro.

Grinblatt, M., and Sheridan Titman. 1989. Mutual Fund Performance: An Analysis of Quarterly Portfolio Holdings. Journal of Financial and Quantitative Analysis, 62(3), 393-416.

Harjito, Agus dan Martono. 2012. Manajemen Keuangan. Edisi Ke 2. Cetakan Ke 2. Yogyakarta: Ekonisia Kampus Fakultas Ekonomi Universitas Islam Indonesia.

Harjono, Timotius, H dkk. 2017. Biaya Operasional Reksadana Sebagai Interverning Pengaruh Karakteristik Reksadana Terhadap Kinerja Reksadana Saham Di Indonesia. Kajian Ilmiah Mahasiswa Manajemen (KAMMA), 6(2), 72-84.

Hayes, Adam. 2020. The Definition of Expense Ratio. www.investopedia.com. Diakses 14 Juli 2020.

Indro, D.C., Hu Jiang C.X., Lee, W.Y. 1999. Mutual Fund Performance: Does Size Matter?. Financial Analysis Journal, 55(3), 74-87.

Iman, Nofie. 2008. Panduan singkat dan Praktis Memulai Investasi Reksadana. Jakarta: Pt Elex Media Komputindo Kompas Gramedia 
Jogiyanto. 2003. Teori Portofolio dan Analisis Investasi. Edisi Ke 3. Yogyakarta : $\mathrm{BPFE}$

Jogiyanto. 2008. Metodologi Penelitian Sistem informasi. Yogyakarta: Andi.

Jogiyanto. 2016. Metodologi Penelitian Bisnis Salah Kaprah dan PengalamanPengalaman. Edisi ke 6. Yogyakarta: BPFE.

Jones, et al.. 2009. Invesments: Analysis and Management (An Indonesian Adaption). Jakarta: Salemba Empat.

Khorana, Ajay and Edward Nelling. 1998. The Determinants And Predictive Ability of Mutual Fund Ratings. Journal of Investing, 7(3), 61-66.

Kon, S. and F. Jen. 1979. The Investment Performance of Mutual Funds: An Empirical Investigation of Timing, Selectivity and Market Efficiency. Journal of Business, 63, 261- 278.

Kuncoro, Mudrajad. 2013. Metode Riset Untuk Bisnis dan Ekonomi, Bagaimana Meneliti dan Menulis Tesis. Edisi 4. Yogyakarta: Erlangga.

Malkiel, B. 1995. Return from Investing in Equity Mutual Fund: 1971-1991. The Journal of Finance, 50, 549-572.

Mulyawan, Setia. 2016. Kinerja Reksadana Syariah dan Beberapa Faktor yang Mempengaruhinya: Studi di Pasar modal Indonesia 2010-2013. Ijtihad Jurnal Wacana Hukum Islam dan Kemanusiaan, 16(2), 217-236.

Nguyen, Ann-Ngoc, Shahid, Muhammad shadiq and Kernohan, David. 2018. Investor Convidence and Mutual Fund Performance in Emerging Market : Insights from India and Pakistan. Journal of Economic Studies, 45 (6), pp 1288-1310.

Otoritas Jasa Keuangan (OJK). Statistik Reksadana 2013-2019. www.ojk.go.id. diakses 2020.

Pambuko, Zulfikar. 2018. Eviews untuk Analisis Ekonometrika Dasar : Aplikasi dan Interpretasi. Magelang : UNIMMA PRESS.

Porter, Gary and Thrif, Jack. 2014. The Career Paths of Mutual Fund Managers: The Role of Merit. Financial Analysts Journal, 70(4), 55-71.

Prabowo, Bartadi. 2018. Analisis Pengaruh Expense Ratio, Market Timing Ability, Fund Age, Fund Size, Dan Fund Cash Flow Terhadap Kinerja Reksa Dana Saham. Skripsi. Universitas Islam Indonesia.

Pratomo, Priyo. E dan Nugraha, Ubaidillah. 2009. Reksadana Solusi Perencanaan Investasi di Era Modern. Jakarta. Gramedia Pustaka Utama.

Sabila, Fadiyah, H dkk. 2019. Stock Selection Dan Market Timing Ability Reksa Dana Syariah Saham Di Indonesia. Journal of Economic, Public, and Accounting (JEPA), 1(2), 68-81.

Satrio, Yusuf dan Mahfud, M, K. 2016. Analisis Pengaruh Total Asset, Fund Age , Expense Ratio dan Portofolio Turnover Terhadap Kinerja Reksa Dana Periode 2012 - 2014. Diponegoro Journal Ofmanagement, 5(2), 1-9.

Segal, Troy. 2020. Turnover Ratio Definition. www.investopedia.com. Diakses 14 Juli 2020.

Sekaran, Uma and Bougie, Roger. 2016. Research Methods For Business. Edisi 7. Chichester, West Susex, United Kingdom: John Wiley and Sons. 
Sharpe, William F. 1996. Mutual Fund Performance. Journal of Business, 39(1), 119138.

Sukmaningrum, G dan Mahfud, M. Kholiq. 2016. Analisis Pengaruh Fund Cash Flow, Fund Size, Fund Longevity, Expense Ratio dan Turnover Ratio Terhadap Kinerja Reksadana, Studi Kasus : Reksadana Pendapatan Tetap Periode Tahun 2011-2015. Diponegoro Journal Of Management, 5(3), 1-11.

Syahid, Nur dan A. Erman, D, 2015. Analisis Pengaruh Stock Selection Skill, Market Timing Ability, Fund Longevity, Fund Cash Flow dan Fund Size Terhadap Kinerja Reksadana (Studi Kasus: Reksadana Saham Periode 2010-2014). Diponegoro Journal Of Management, 4(4), 1-11. 